\title{
移動ロボットの遠隔操作による美術館鑑賞 一感性特プロにおけるロボットの役割
}

Appreciation in the Remote Museum by Remote Control of a Mobile Robot -Role of Robot for Special Project on Modeling the Evaluation Structure of KANSEI-

前山祥 一*1 油田信 一*1 原田昭*2

*1 筑波大学電子・情報工学系 $* 2$ 筑波大学芸術学系, 感性評価構造モデル構築特別プロジェクト Shoichi Maeyama*1, Shin'ichi Yuta*1 and Akira Harada*2

${ }^{* 1}$ Institute of Info. Sci. and Electronics, ${ }^{* 2}$ Institute of Art and Design, Univ. of Tsukuba

\section{1.はじめに}

近年, インターネットの WWW 技術とロボットの知能 化技術を組み合わせることで, 自宅から，そして，世界中 から，ロボットを動かすことが技術的に可能になってきて いる，一方，工業製品は，機能よりもデザインが重視され る傾向にあり，消費者の嗜好・感性にあった製品デザイン が求められている. 筑波大学の感性評価構造モデル構築特 別プロジェクトは，このような時代を背景に発足した学際 的な研究プロジェクトである。本稿では，ネットワーク・ ロボティクスと関連する話題を中心に, 感性特プロを紹介 する。

\section{2. 感性評価構造モデル構築特別プロジェクトとは}

筑波大学では, 現在, 三つの特別プロジェクトによる研 究が並行して進められている. 特別プロジェクトとは, 学 問分野の枠を越えた学際的な研究を行うことを目的とした 3 年から 5 年の期限付き研究組織である. 感性評価構造モ デル構築特別プロジェクト（略称：感性特プロ）は, 平成 9 年度から平成 13 年度までの予定で, 原田昭プロジェクト 長 (芸術学系教授) とプロジェクト専従教官（最大 6 人） を中心に, 学内の研究員約 25 名, 学外の客員研究員的 30 名の協力により進められている.

図 1 は，感性特プロの研究構成図を示したものである. 各分野が互いに関連しながら, データの収集, 解析, モデ ル作りを行う構造になっている.この研究の構造は, 以下 のように整理できる。

遠隔鑑賞ロボットの開発 ビデオカメラを搭載した遠隔操 作ロボットをインターネットにつなぎ，実在の美術館

原稿受付 1999 年 2 月 1 日

キーワード : Mobile Robot, Remote Control, Appreciation Robot, KANSEI Evaluation, WWW (World Wide Web).

*1 ₹ 305-8573つくば市天王台 1-1-1

*2 个 305-8574つくば市天王台 1-1-1

*1 Tsukuba-shi, Ibaraki

${ }^{* 2}$ Tsukuba-shi, Ibaraki
で美術・デザイン作品などの実作品を遠隔地から鑑賞 評価する実験を行う。

感性データ・ベースの実現 遠隔操作によるロボット操作 データの記録を収集し蓄積し, 操作者の鑑賞行動の データとしてデータベース化する。

感性評価モデルの構築 データベースに蓄積された鑑賞評 価デー夕を解析することにより，人々の作品鑑賞にお

ける態度モデルを明らかにする。

研究組織は, 以下の三つの研究グループに分かれている. 最終目標である「感性に基づくデザイン作品の評価構造モ デルの構築」に関連して, 各グループのテーマに沿った研 究を同時進行で行う形態をとっている.

グループ 1 美術・デザイン作品の感性評価構造に関する

研究 (グループ長: 芸術学系原田昭教授)

グループ 2 広域ネットワークにおけるマルチメディア・

データベースに関する研究（グループ長：社会工学系

松田紀之教授)

グループ 3 鑑賞ロボットの遠隔操作に関する研究 (グルー

プ長：電子・情報工学系 油田信一教授)

グループ 1 には, デザイン学, 芸術学, 美学, 哲学などの 分野の研究員が属しており, 工業デザイナ, 美術評論家, 画家など, 多様な立場から作品評価の構造が研究されてい

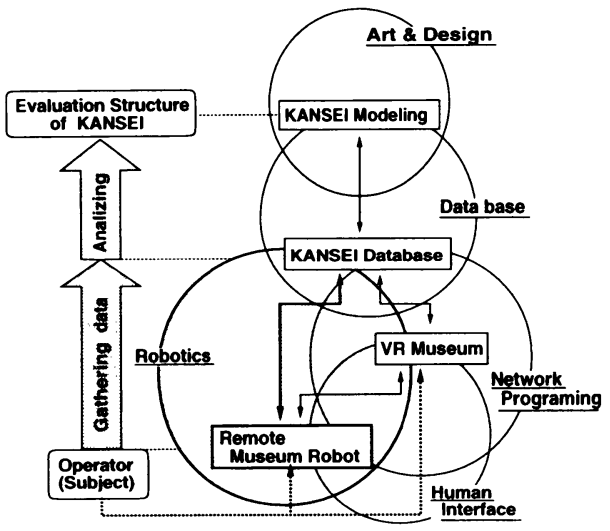

図 1 感性特プロの研究構成図 


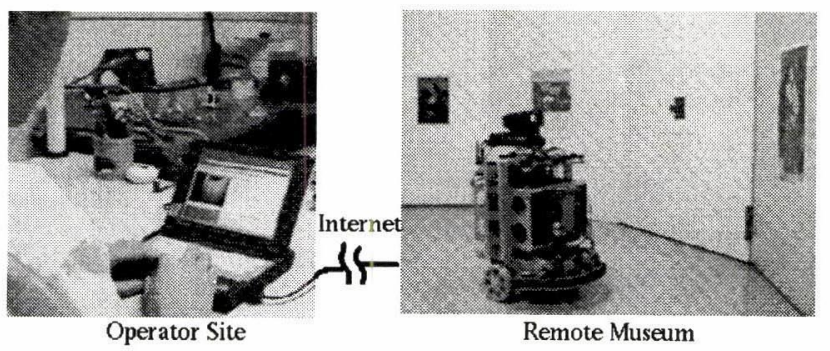

図 2 遠隔鑑賞ロボットの概略図（左：操作者と操作端末，右：美術館内のロボット）

る.グループ 2 には, 情報分析, データベース, 分散シス テムなどの分野の研究員が属しており，マルチメディア． データベースやネットワーク・プログラミングの技術を用 いて, 実験データの解析に必要な加工やデータの収集のた めのツール作りが行われている。また，グループ 3 には， ロボティクス,バーチャル・リアリティなどの分野の研究 員が属しており，操作者の代わりとなって実際の美術館に 存在するロボットとそれを快適に遠隔操作するための装置 作りが行われている。すなわち，ロボットは，鑑賞評価の 実験データ獲得ツールとしての役割を果たす。

\section{3.なぜロボットが必要か?}

WWW 上の美術館としては，実際の美術館ではなく，コ ンピュータ内にデータを入れて仮想的に構築した美術館 (以下，VR 美術館）の方がむしろ一般的である。感性特 プロの鑑賞実験も，このVR美術館でもある程度行えると 考えられる。しかし，VR美術館の鑑賞は，実際の美術館 を訪れる場合と趣や印象が異なる。それは，VR美術館作 成時のモデル化・抽象化の影響であろう。これらの影響が， 鑑賞行動や作品評価にどのような影響を与えるかは，今の ところ分かっていない。一方，ロボットから実際の美術館 内の映像を送ってもらう作品鑑賞方法は，あるがままの美 術館をそのまま利用するので上記のような問題は起こらな い.しかし，この方法も，5章で詳しく述べるように技術 的な問題を多く抱えている。そこで，感性特プロのグルー プ 3 としては，ロボティクスを中心に，これらの技術的課 題を克服すべく研究を進めている.

感性特プロでは，ロボットを用いた実験データの収集を 中心に置いているが, 同時にVR 美術館も構築している. ここで構築中の VR 美術館は, ネットワーク・プログラミ ングの研究者らを中心に, VRML とモーバイル・オブジエ クトの技術を活用して実現される予定である。最終的には， 両者から得られる鑑賞行動の実験デー夕を比較することに より, その相違から興味深い研究成果が得られるであろう.

\section{4. 遠隔鑑賞ロボットとは}

グループ 3 では，上に述べた目的のために,「遠隔鑑賞ロ
ボット」を開発している。これは, 整理すると以下のよう なものである(図 2 ).

(1) 遠隔地の人間によりコンピュータネットワークを使っ て制御され，美術館の中を動き回る.

（2）そこで得た映像や音声を遠隔地で制御している人間に 提供する。

（3）それにより，遠隔地の人間は，あたかも美術館の現場 にいるのと同じ気分で作品を鑑賞することができる.

(4)これと同時に, 遠隔の人が美術館を「訪れる」とき, ロボットの動きや送られた映像の記録を残し、「訪問 者」の美術館内での行動を記録することができる.

(4) が, 感性評価モデルを構築するもととなる実験デー夕 であり，(1)〜 (3) を実現できるロボットを開発することが, 本プロジェクトに拈けるロボティクス分野の研究者の役割 である。

\section{5. 遠隔鑑賞ロボットの実現のための技術的課題}

遠隔鑑賞ロボットを実現するには, 以下のような技術開 発が必要である。

・伝送時間遅れに強い移動ロボットの操作方式

・限られた通信バンド幅での臨場感の提示方法

・移動ロボットと基地局の無線通信システム

・遠隔操作と自律制御の融合による行動制御

・美術館で動く移動ロボット・システムの開発

Web ブラウザを用いたインターネットを介した WWW 上での遠隔操作を目指しているので, 操作者と美術館を結 ぶネットワークの負荷は, 動的に変化する。つまり，いつ 操作者側からの指示がロボットに届き，実行されるかは， 不定である。また，クライアント側の操作者が快適に操作 を行うには，遠隔地にあたかもいるような臨場感を提示す る必要があるが，そのためには，大量の情報を美術館側か ら操作者側に伝送する必要がある。しかしながら，限られ た通信バンド幅では，必要な時間内にすべての情報を送る ことが難しく，結果として遅れて提示されることになる． この遅れにより，臨場感を得るのは非常に難しい。これに 加えて, 移動ロボットの場合, 指示された操作の実現にも 時間がかかる，例えば，目的地を指示したとしても，すぐ 
には到達できない。しかし, 操作者側からみた映像では, 伝送遅れによるものなのか, まだ目的地についていないの かが区別しにくい.

移動ロボットと基地局（美術館側に置かれたサーバ側の 計算機）との無線通信も問題である。ロボットが 1 台の場 合はよいが，複数台のロボットを同じ美術館内で働かせる 場合，基地局を含む複数ロボット間通信のシステムを実現 する必要がある。

さらに，伝送時間遅れのある状況では，ある程度の自律 的なロボットの行動も必要となる。例えば，障害物に衝突 しそうなときや，すでに障害物に接触しているときなど は操作指示がなくても停止して，ロボット自身が損傷を受 けたり，相手を壊したりしないようにするべきである。ま た，初期位置への帰還や充電など，操作者の指示とは独立 に行って欲しい自己管理や自己保存の能力もある。実際に， ロボットを動かすためには，これらの自律制御能力と遠隔 操作指示をうまく融合させる必要がある.

最後に，美術館で動くのに適した移動ロボットを開発す る必要がある。美術館は，一般の来訪者が往来し，大学な どの研究室に比べると一回りロボットに不親切である。ま た，美術館の景観を乱すものであってもいけない。そもそ も，美術館は，人間が鑑賞することを前提に作られた環境 であり，ロボットの方がその条件に合わせられなければな らない。したがって，鑑賞のためのロボット視覚は，人間 の目の位置とほほ同じ位置にあることが期待される。しか し，人間が通り抜けられる出入口や通路を通り抜けられる 必要があるので，底面積はそれほど大きくできない。した がって，ひょろっと高いロボットにならざるを得ず，それ をふらふらせずに安定して走行制御する必要が生じる。

\section{6. 遠隔鑑賞ロボットの開発状況}

前章で述べた技術的課題に取り組むことで，筆者らの研 究グループでは，すでに，感性特プロの遠隔鑑賞ロボット に関していくつかの研究成果をあげている.

論文 [1] [2]では, 時間遅れの影響を受けにくい遠隔操作 コマンド系として, 絶対位置情報上書き型の操作コマンド 系を提案した。ここでは, 操作者には, ロボットから送ら れる画像のみを提示し, 画像上で行きたい地面の位置を指 し示す操作インターフェイスを用いた。本手法の長所は, 送る情報が画像だけでデー夕の転送量が少ないこと, 環境 地図デー夕などの事前知識を必要としないことである。必 要なのは, 路面が平らであるという条件のみである。し たがって,このシステムは, 実際の美術館にそのまま持ち 込み、インターネットに接続するだけで利用できる。論 文 [1] [2] を発表した際は，Webブラウザではなかったが， 現在は, Webブラウザ上で同様のシステムが実現されて いる。

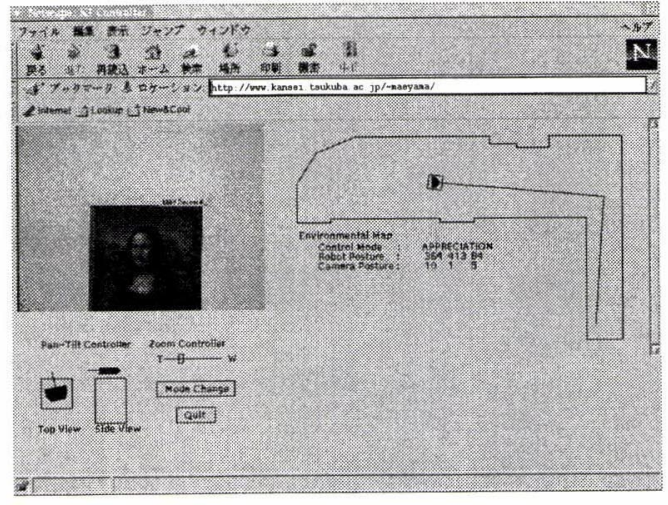

図 3 WWW ブラウザ上に構築された遠隔操作インターフェ イス

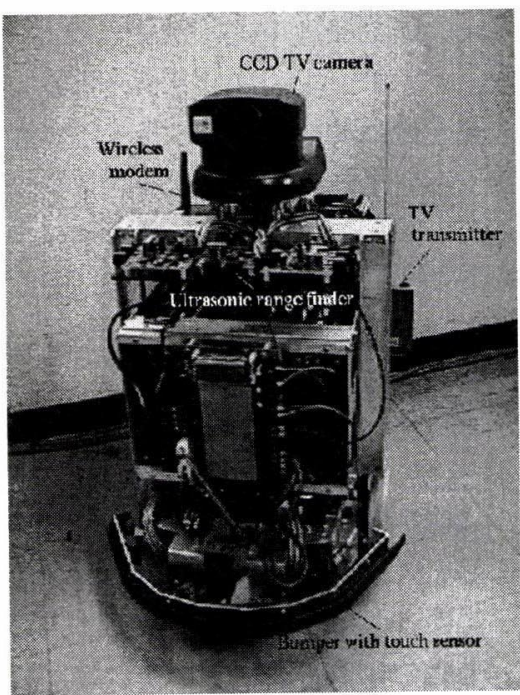

図 4 遠隔鑑賞ロボット「山彦 $\mathrm{K} 1 」$

さらに,より快適な遠隔操作を行うため, 美術館内の環 境地図やその地図の上でのロボットの現在位置姿勢の提示 を行う研究も行っている. 図 3 は, その操作インターフェ イスである。この方法では，事前に美術館のレイアウト図 を作成する必要があることや実環境と地図に提示されてい るデー夕を同一に保つ必要があることが問題となるが，画 像だけでは死角になって見えない部分や環境全体の中での ロボット (=自分) の位置が把握しやすくなる。このよう なシステムを実現し, 米国カーネギーメロン大学からの遠 隔操作実験を行った結果，提示される情報が多くなっただ けでは，快適にはならず，正しく，かつ，同期した情報が 提示されなけれ混乱するだけであることが確認された。 現在，この点を改良し引き続き研究を進めている．今後の 学会活動の中で随時成果を報告していきたい.

美術館側で動いているロボットは, 筑波大学の知能口 ボット研究室で開発された自律移動ロボット「山彦」に, パンチル夕付き TVカメラと画像・デー夕の無線通信装置 
を実装し実現した。このロボット「山彦 K1」（図 4)は， 障害物の検知や衝突の検知など自己を保存する機能は自律 的に行い, 自己を破壊しない範囲で遠隔からの操作指示に 従って動くシステムになっている。また，初期位置への帰 還などのあらかじめ決まっているルーチン・ワークや現在 位置推定などのロボット自身の現在状態の把握も自律的に 行うことができる.

\section{7. 今後の研究開発計画について}

現在, 筑波大学近辺の実際の美術館での実験を計画中で ある. 初めは, 筑波大学芸術学系関係の展示に合わせて, その期間，ロボットを置かせてもらうことを予定している. また, ロボット工学とデザイン学の共同研究で, 美術館に 存在することを意識したスタイリングをもつ移動ロボット を開発中である。これまで実験に用いてきた移動ロボット 「山彦 $\mathrm{K} 1 」$ は, 高さ $60[\mathrm{~cm}]$ の背の低いロボットであった が, 新たに開発中の感性特プロ・オリジナルロボットは, 人間の目の高さに視覚をもたせ, 実際の美術館で人間とほ ぼ同じ視点の映像が得られるようになっている。

なお, 現在のところ遠隔操作インターフェイスの URL は, 開発中のため一般には公開していない。しかし, いろい ろなサイトから操作してもらうことで開発が進むので, 実 験に御協力いただける方は大歓迎である。ご興味ある方は 前山まで Eメール（maeyama@kansei.tsukuba.ac.jp）を いただければ幸いである。

\section{8. ま と め}

本稿では, 筑波大学の感性評価構造モデル構築特別プロ
ジェクトを紹介し，このプロジェクトとロボティクスの接 点である「遠隔鑑賞ロボットの開発」について述べた。感 性特プロを開始して 2 年が終わったところであり，ようや く下準備が整いつつあるところである [3] [4]. 感性特プロ の面白いところは, 他の研究分野, 特にデータベースや ネットワーク・プログラミングの技術とロボティクスの技 術をどうつなぐかということに真剣に取り組む機会を提供 していることである。また, 開発した研究用のロボットが, ロボット研究者以外の多数のユーザに実際に使ってもらえ ることもありがたい，さらに，実際の美術館に置かれるこ とで一般の人とのインタラタションが生まれることも期待 される，そして，感性特プロ「遠隔鑑賞ロボット」が，研 究から生活に近い場面での知能ロボットの利用, 人間と知 能ロボットの共生に向かう実践的な第一歩として貢献する ことを望んでいる。

\section{参 考 文 献}

[1] 前山祥一, 油田信一, 原田昭：“遠隔地の美術館内を鑑賞するための 移動ロボットの操作方式”, 第 16 回日本ロボット学会学術講演会予 稿集, pp.1003-1004, 1998.

[2] S. Maeyama, S. Yuta and A. Harada: "Mobile Robot in the Remote Museum for Modeling the Evaluation Structure of KANSEI, Proceedings of 7th IEEE International Workshop on Robot and Human Communication, vol.1, pp.315-320, 1998.

[3] 感性評価構造モデル構築特別プロジェクト編：“感性評価 1”, 筑波 大学感性評価構造モデル構築特別プロジェクト研究報告集, 平成 10 年 3 月.

[4] 感性評価構造モデル構築特別プロジェクト編：“感性評価 2”，筑波 大学感性評価構造モデル構築特別プロジェクト研究報告集, 平成 11 年 3 月発行予定.

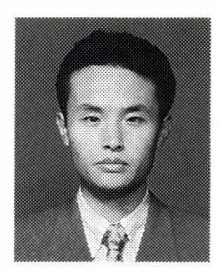

前山祥一（Shoichi Maeyama）

1971 年 2 月 10 日生. 1993 年筑波大学第三学 群情報学類卒業. 1997 年筑波大学大学院博士 課程工学研究科中退. 同年筑波大学電子. 情 報工学系助手. 感性評価構造モデル構築特別 プロジェクト専従教官として, Webブラウザ を用いた移動ロボットの遠隔操作の研究に従 事, 現在に至る。移動ロボットの屋外ナビゲーション, ランド マークの認識, および, 現在位置認識のための複数センサ情報 の融合にも興味を持つ. 博士 (工学). IEEE, 日本感性工学会 所属.

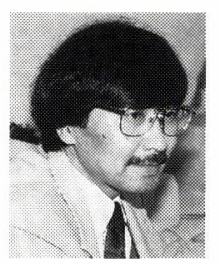

原田 昭 (Akira Harada)

1942 年生. 1964 年東京教育大学教育学部芸 術学科卒業. (株) GK インダストリアルデザ イン研究所を経て, 1978 年より筑波大学芸 術学系. 現在, 教授. 1996 年博士 (デザイン 学). 1985 年イリノイ工科大学客員研究員. 専門: 感性情報科学, インターフエイスデザ イン. 1972 年ガラス家具 (旭硝子) デザインで通産大臣賞. 著 書：(翻訳）ヒューマンインターフェイス・デザインの設計方法 (マグロウヒル出版) 所属学会：日本デザイン学会副会長, 日本 感性工学会, インダストリアルデザイナー協会会員.

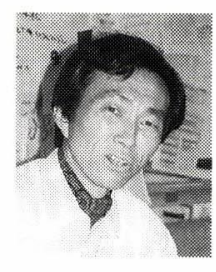

油田信一 (Shin'ichi Yuta)

1948 年 3 月 23 日生. 1975 年慶應義塾大学大 学院 (電気工学専攻) 修了. 現在, 筑波大学 電子情報工学系教授. 知能移動ロボット, ロ ボットセンサ，ロボット用コントローラなど の研究に従事. 自動制御や信号処理の理論と 応用に興味を持つ. 工学博士. IEEE, 計測自 動制御学会などの会員. 